Annals of Warsaw University of Life Sciences - SGGW

Land Reclamation No 38, 2007: 139-150

(Ann. Warsaw Univ. of Life Sci. - SGGW, Land Reclam. 38, 2007)

\title{
Modelling in support of an interdisciplinary approach to ecosystem restitution
}

\author{
MARK HENRY RUBARENZYA ${ }^{1}$, JAN STAES ${ }^{2}$, PATRICK WILLEMS ${ }^{1}$, \\ JEAN BERLAMONT ${ }^{1}$, PATRICK MEIRE ${ }^{2}$ \\ ${ }^{1}$ Department of Civil Engineering, Katholieke Universiteit Leuven, Belgium \\ ${ }^{2}$ Ecosystem Management Research Group, University of Antwerp, Belgium
}

\begin{abstract}
Modelling in support of an interdisciplinary approach to ecosystem restitution. This paper reports on a study being undertaken to analyze the potential effects of rewetting when undertaken for the restitution of the catchment ecosystem of the Grote Nete catchment. In bringing together the expertise of both ecological and hydrological modelers, this study aims at ensuring that the science being performed is immediately relevant from both the environmental management and the socio-political perspectives. Like many European catchments, Grote Nete has been experiencing an increase in extreme hydrological events. In addition, there has been a decline in the ecological value of the catchment ecosystem. The problem is considered to be a conflict of interests arising between urban/agricultural and nature conservation needs. Rewetting has been considered as a possible intervention to reverse these trends. However, a shortcoming with rewetting is that the hydrological consequences remain largely unknown. A numerical model has been developed to study these potential effects. A land use model, SPAN was developed and coupled to a physically-based, fully distributed model (MIKE SHE) to complete an ecohydrological model. The paper describes the development of the model.
\end{abstract}

Key words: ecohydrological modelling, SPAN model, MIKE SHE model, catchment rewetting.

\section{INTRODUCTION}

In the Grote Nete catchment (north-eastern Belgium), river valley rewetting is one of themeasures being considered for the restoration of the regional ecological value. Like much of Europe, this region has experienced anthropogenic change which was characterised by significant land drainage. The problem is a classic conflict of interests between agriculture and nature conservation needs. During the last century, significant degradation has been observed in wetlands, mainly due to changes in hydrology and water quality. This was partly the result of large scale agricultural intensification that included increased drainage of former wetlands, fertilizer application, and changes of crop-type and parcel-size. The increased extraction of groundwater, the loss of infiltration area resulting from increased paved areas (Liu et al., 2006), and the extensive drainage of agricultural land have resulted in reduced groundwater levels, and have decreased the influence of upward seepage in the root zone of the soil. This human-induced change in the hydrologic regime is believed to have led to the endangerment of certain flora and fauna, and the seasonal shifting between droughts and flooding. It has also been observed that the incidence of extreme hydrological events has increased in magnitude and intensity over the last century (Rubarenzya et al., 2005). These changes to the ecosystem have in-turn 
resulted in an ecological imperative for conservation, along with the associated socio-political considerations, and hydrological concerns.

Water resources management has for long been considered a matter of engineering. More recently there has been a shift towards a more integrated management. This requires new tools and models of great diversity, capable of integrating multiple aspects of the water system and its management. An ecosystem based management strategy is one of the many emerging approaches for basin management. It focuses on allowing society to harness the functioning of ecosystems and ensure the sustainable use of resources, services and goods that they provide (Jewitt, 2002). A key aspect of this approach is that the maintenance of diversity in ecosystems builds resilience against large disturbances (Jewitt, 2002). Ecohydrology is closely related to this concept (Zalewski, 2000), but often narrows it down to the interactions between ecology and hydrology. In practice, bi-directional interactions are usually not considered and true interdisciplinary research is limited (Hannah et al., 2004). This is mainly due to "not understanding" the theoretical underpinning of the other discipline (Hannah et al., 2004), a phenomenon that Hunt referred to as the "black box syndrome" (Hunt and Wilcox, 2003). The need for interdisciplinary collaborative research is imperative as history shows us that managing hydrology goes beyond flood defence and has a wide range of ecological and socio-economic impacts (Bond, 2003).

The overall objective of this research study is to determine, through scenario analysis, whether a reversal of the anthropogenic catchment drainage activities will (a) have the desired effect of rewetting the land, and/or (b) aggravate the increasing trend in flooding. The specific objectives include the construction and use of a distributed, physically-based hydrological model, incorporation of ecological, socio-political, andengineering considerations, and the generation and testing of realistic rewetting scenarios. This paper reports on the first phase of research. The hypotheses were that (a) an interdisciplinary team of ecologists and engineers is important for the realistic undertaking of an ecosystem restoration study, and (b) a distributed, physically-based hydrological model will realistically represent the river discharge in the Grote Nete catchment.

River valley rewetting was defined as the process of re-hydrating an area that had previously experienced dehydration through drainage. Such drainage would have occurred for agricultural or human settlement development. Re-hydrating may be through surface or groundwater rewetting. Methods proposed for rewetting include the installation of new wetlands; the restoration of natural flood plains, for instance, through the removal of dykes; and by river level regulation.

\section{Background to interdisciplinary study}

The study team initially comprised of engineers. However, it soon became evident that the expertise of biologists and ecologists would be required for an integrated understanding of the ecosystem and the planning of rewetting scenarios. A group of ecologists and biologists were then co-opted into the 
team. The latter then developed the spatial analysis tool (an ecological model) that was used for scenario development. One of the stated goals in team building was to establish good communication between the two groups of scientists, and attain a more realistic understanding of the natural system in so doing. For a successful outcome it was also necessary to achieve compatibility between hydrological and ecological modelling tools. Figure 1 illustrates the modelling approach adopted, which comprised of ecohydrological modelling and extreme value (EV) statistics.

\section{METHODS AND MATERIALS}

\section{The study area}

The study area is located in Flanders, 60 $\mathrm{km}$ north-east of Brussels (Fig. 2). It is $385 \mathrm{~km}^{2}$ and is part of the Grote Nete basin within the Central Campine region. It has a moderate rolling landscape and the topography ranges from 14 to $65 \mathrm{~m}$, with an average of $34 \mathrm{~m}$ above sea level. After an initial strong drop in elevation from the Campine Plateau the topography decreases very gradually from east to west. The boundary between the Campine Plateau and the lower western area is situated around the topographic level of $35 \mathrm{~m}$. The terrain ranges between $0-5 \%$ gradient, with a mean slope of

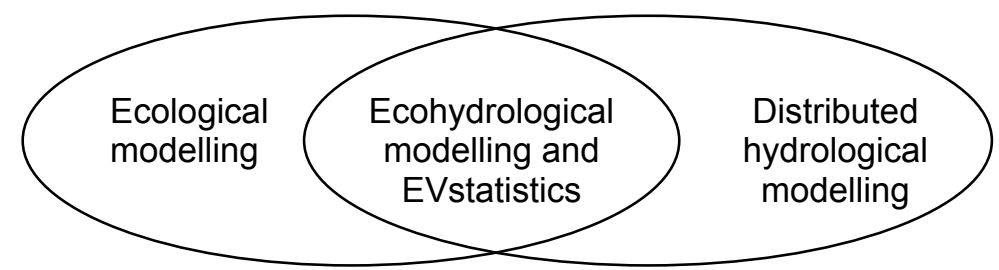

FIGURE 1. The modelling approach comprising of ecohydrological modelling and extreme value (EV) statistics

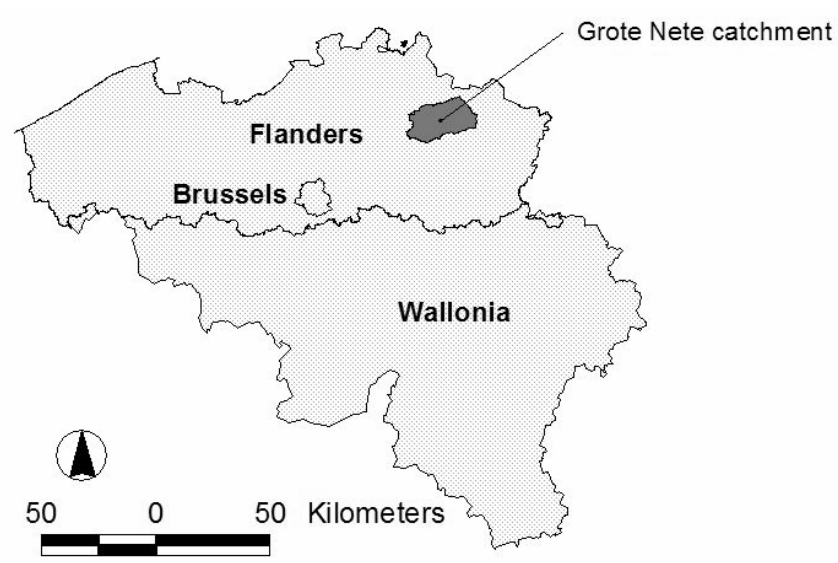

FIGURE 2. Map showing the location of the study area in Belgium. The figure also shows the 3 main political regions of the country 
$0.3 \%$. The catchment is characterized by the Grote Nete, Molse Nete, and Grote Laak Rivers and their tributaries, and includes a dense network of agricultural drains. The Grote Nete River originates at the foot of the north-western edge of the Campine plateau.

Geologically the area belongs to the Campine basin, a subsidence area north of the Massive of Brabant. From late Cretaceous until end of the Tertiary, the basin experienced a second major subsidence period with deposition of marine sediments. During the Quaternary, thick sediments were deposited by the Rhine and Meuse rivers in the eastern part of the area, which now constitute part of the Campine Plateau (Gullentops and Vandenberghe, 1995). The Quaternary and Tertiary (until Miocene) deposits consist mainly of sandy formations, the most important being the glauconite rich Diest formation with a thickness of up to $90 \mathrm{~m}$ (Schiltz et al., 1993). The early Oligocene heavy clay of the Boom Formation forms the base of the sandy aquifer system. The average precipitation in the area ranges from 743 to $800 \mathrm{~mm} / \mathrm{y}$. The dominant soil type is sand, with sandy loam, loamy sand, and silty loam in the valleys. The land use is categorized into 8 classes including maize $(35.7 \%)$, paved areas $(23.5 \%)$, grassland $(20.8 \%)$, leaf forest $(14.7 \%)$, pine forest $(3.1 \%)$, open water $(1.3 \%)$, bare soil $(0.6 \%)$, and wetlands $(0.3 \%)$.

\section{MIKE SHE}

MIKE SHE (Refsgaard and Storm, 1995) is a physically based, fully distributed model for simulating the entire land phase of the hydrologic cycle. It is an integrated modelling environment that allows components to be used independently. Being physically based means that model parameters can be measures in the field, and have a physical meaning. Distributed hydrological modelling refers to the process by which an area under study is assigned both spatial and temporal representation within a model. The method is based on the blueprint of Freeze and Harlan (Beven, 2001). Their main promise lies in the promise for scenario generation where no calibration information is possible (Smith et al., 1994; Beven, 1985; Beven, 2001). The technique offers the best approximation of physical reality, especially when physically-based parameter sets are used for the models.

MIKE SHE includes all of the processes in the land phase of the hydrologic cycle (including precipitation, evapotranspiration, canopy interception, overland sheet flow, channel flow, unsaturated sub-surface flow, and saturated groundwater flow. Each of these processes can be represented at different levels of spatial distribution and complexity, according to the goals of the modelling study, the availability of field data and the modeller's choices (Graham and Butts, 2005).

\section{SPAN tool}

The spatial analysis tool (SPAN) (Staes and Meire, 2006) was developed to assist in the elaboration of the Nete River Basin Management Plan (RBM), allowing the planning team to assess both current and future land use. It also allowed 
to support a long-term vision on spatial planning that incorporated aspects of water system functioning. SPAN included four types of land-use (agriculture, residential, industry and nature) and three aspects of water system functioning (infiltration, wetland water conservation and floodplain water storage). The procedure followed in developing the RBM plans is illustrated in Figure 3. The tool functions by assessing a stakeholder land use claim for a parcel, X, against the corresponding physical suitability for the same parcel, and obtaining a compromise position through negotiations. The stakeholder land use claims are obtained during stakeholder workshops, while the physical suitability is determined by expert judgment of scientists. Credibility analyses incorporates additional information pertaining to the juridical legitimacy of the claims, especially with regard to options for protection, restoration, or mitigation measures on the land parcel and indicate the appropriate strategies for negotiation.

\section{Equations for the physical processes}

The overland flow component was defined by the two-dimensional diffusion wave approximation of the St. Venant equations governing shallow water flow. The river network (Fig. 4) was represented in MIKE 11 (Havno et al., 1995), which is the hydrodynamic model that is coupled to MIKE SHE and simulates the one dimensional river flows and water levels using the fully dynamic St. Venant equations.

A simplified form of Richards' equation (equation 1) was used to represent flow in the unsaturated zone.

$$
\frac{\partial \theta}{\partial t}=-\frac{\partial q}{\partial z}-S(z)
$$

where $\theta$ is the volumetric soil moisture, $K(\theta)$ is the saturatedhydraulic conductivity, $S$ denoted the root extraction sink term. For the gradient of the hydraulic head, the simplified Richards equation ignores the pressure head term and the driving force is due entirely to gravity.

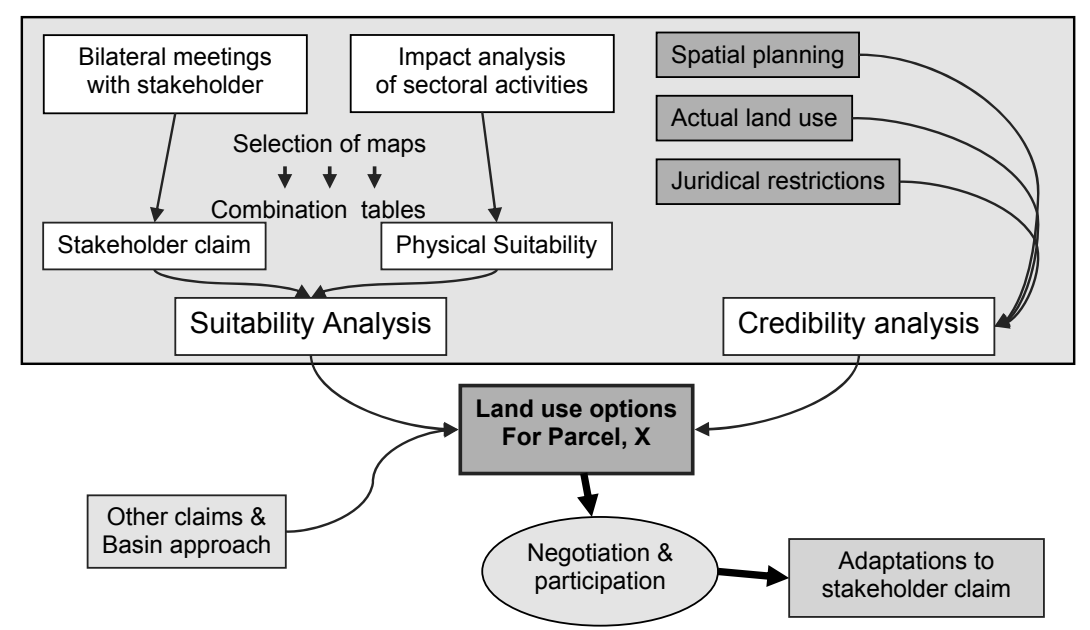

FIGURE 3. Spatial analysis for any Parcel, X 


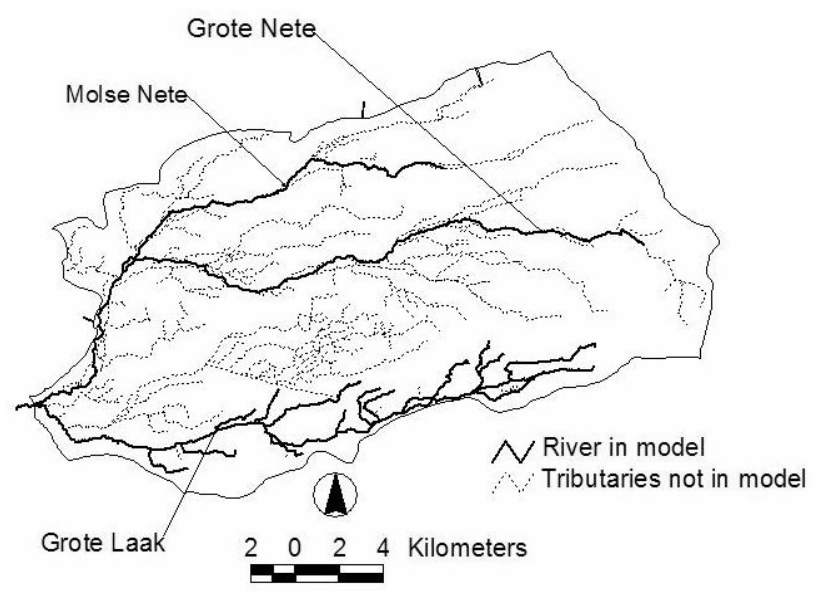

FIGURE 4. Schematisation of the river tributary network of the Grote Nete catchment. The figure highlights those tributaries included in the river model

The saturated zone model consisted of a 3-dimensional Darcy equation. This permitted three-dimensional flow in the heterogeneous aquifer with shifting conditions between unconfined and confined conditions. The spatial and temporal variations of the dependent variable (the hydraulic head) were described mathematically within the equation (equation 2), which was solved numerically by an iterative implicit finite difference technique.

$$
\begin{aligned}
& \frac{\partial}{\partial x}\left(K_{X} \frac{\partial h}{\partial x}\right)+\frac{\partial}{\partial y}\left(K_{Y} \frac{\partial h}{\partial y}\right)+ \\
& +\frac{\partial}{\partial z}\left(K_{Z} \frac{\partial h}{\partial z}\right)-Q=S \frac{\partial h}{\partial t}
\end{aligned}
$$

where $K_{X}, K_{Y}, K_{Z}$ represent hydraulic conductivity along the $\mathrm{x}, \mathrm{y}$, and $\mathrm{z}$ axes, $h$ represents the hydraulic head, $S$ represents the specific storage coefficient, and $Q$ represents the source/sink terms.

Evapotranspiration was modelled by the Kristensen-Jensen model (Kristensen and Jensen, 1975). The model is based on empirically derived equations derived from field measurements.

A multi-criteria protocol was adopted in model development (Rubarenzya et al., 2006a). The model was calibrated against daily data from the Varendonk hydrological station located at the catchment outlet, and was done by the split-sample method, with the calibration period from 1986-1988, and a validation period from 1990-1995. Hourly discharge data was available for these periods.

\section{Land use representation}

Land use generally refers to human employment of the land (Samaniego and Bardossy, 2006; Niehoff et al., 2002). An appropriate land use representation of the Grote Nete catchment was the first step in the development of the ecological component of the ecohydrological model. Catchments like the Grote Nete represent open, highly complex systems, whose complexity arises from the fact that they are comprised of a large 
number of tightly coupled subsystems that interact in both time and space at different scales. Thus, it is recognised that there is considerable uncertainty in our knowledge of the component processes, and in the representation of our knowledge in building models of the system (Refsgaard, 1997; Beven, 2002). Tradeoffs are required to achieve an acceptable level of complexity. However, the land use represented by a model should bear sufficiently good resemblance to reality while preserving the systems adaptability and creativity (Samaniego and Bardossy, 2006). In other cases, simplification results from a lack of data on effective land use and corresponding parameterisation. The sensitivity of hydrological models to land use input has been studied before and is a known source of modeling uncertainty (Breuer et al., 2003; Eckhardt and Arnold, 2001). Examples of this uncertainty are the possibility of an incorrect or unrealistic hypothesis on classification (Parent and Bernier, 2003) and errors in digitization of data (Burrough, 1998). The sensitivity of hydrological models to land use input has been studied before and is a known source of modeling uncertainty. Examples of this uncertainty include the possibility of an incorrect or unrealistic hypothesis on classification (Parent and Bernier, 2003), and errors in digitization of data (Burrough, 1998). The determination of land use can be done from different viewpoints. This study approached the subject from the viewpoint of integrated water management. The study compared three land use maps: Landsat TM, Corine Land Cover (CLC), and a map that is used for the drawing up of the basin management plan (BMP) for the Nete basin.

\section{RESULTS}

The modeling outcome of this collaborative research includes a site-specific physically-based, fully distributed hydrologic model for the Grote Nete catchment, and a spatial analysis land management tool. Used together, this 'ecohydrological model' is then able to generate realistic scenarios of rewetting and test them for effects on extreme hydrological events. The simulated discharge time series for the catchment's outlet limnigraphic station at Varendonk (Fig. 5) had Mean Square Error values of 0.11 and

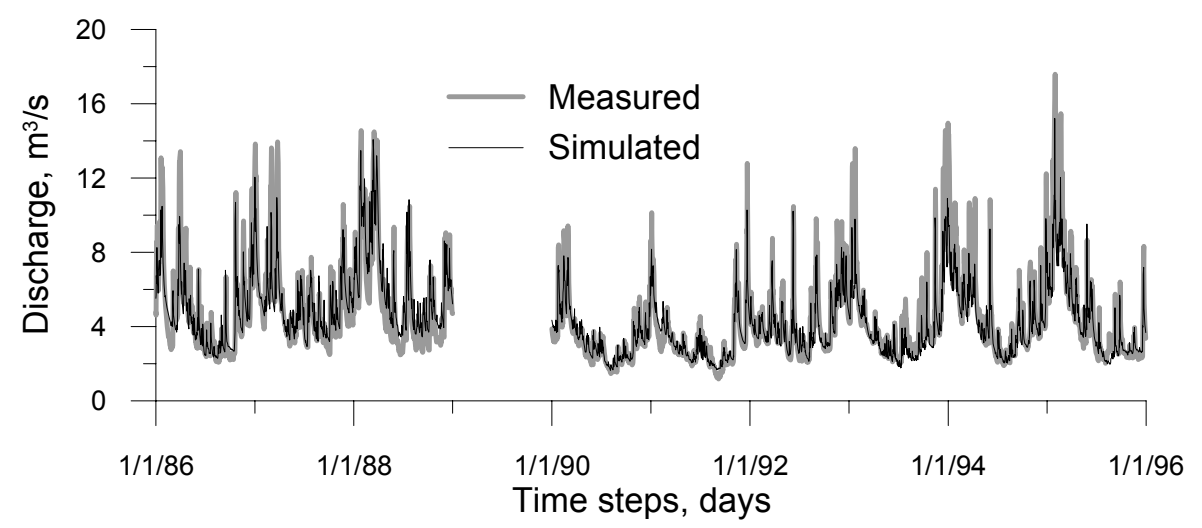

FIGURE 5. Daily discharge time series for calibration and validation periods at Varendonk 
$0.07\left(\mathrm{~m}^{3} / \mathrm{s}\right)^{2}$ over the calibration and validation periods. The Nash and Sutcliffe Efficiency coefficient was 0.74 and 0.81 respectively, for the same periods.

Modeling of the flow volume was checked with a Q-Q plot of cumulative volumes (Fig. 6), and the results were good over both the calibration and validation periods.

Regarding the study on land use representation, only a third of the basin is shown to have the same land use on the three maps. Up to $60 \%$ of the land use is the same for two maps, while having a different land use for the third map. The acreage totals for the land use maps differ both in acreage and in positional errors.
Table 1 indicates a large variance for maize, leaf forest, wetlands and grassland land use classes, with wetlands having the largest variance across the different maps (Fig. 7). Open water, built-up areas and pine forest show less variance in acreage across the three maps.

\section{DISCUSSION AND CONCLUSIONS}

Figure 7 shows the variation of individual land use types against distance from the streams within the catchment. In the figure, the distance themes are grouped into 25 equal area classes. Land use
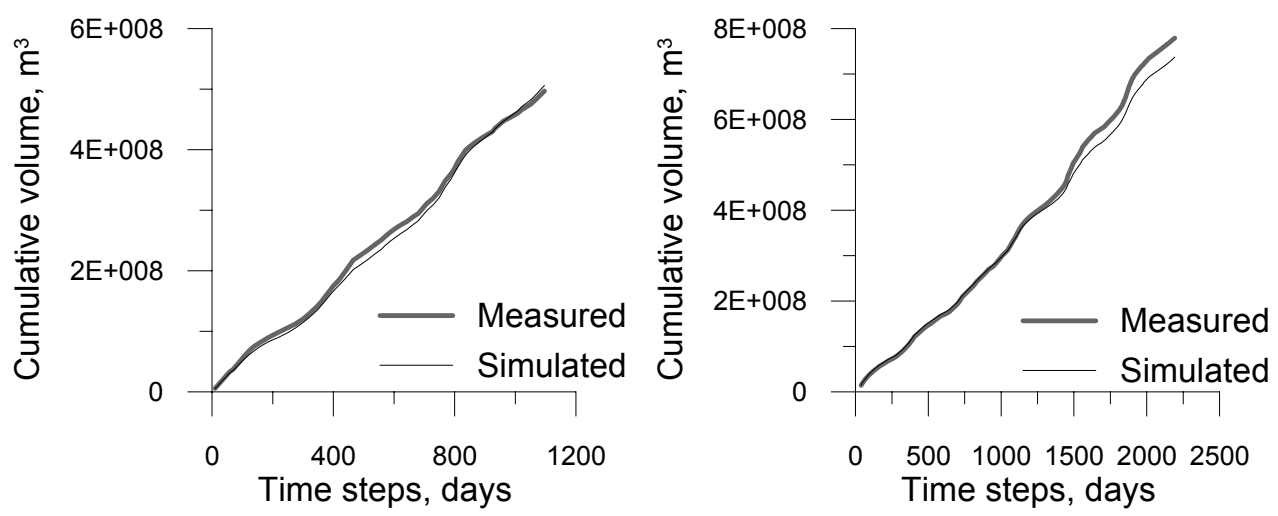

FIGURE 6. Cumulative daily discharge at Varendonk for the calibration (left) and validation periods (right)

TABLE 1. Percentage acreages for different land uses in the different maps of the Grote Nete catchment

\begin{tabular}{|l|c|c|c|r|r|r|}
\hline & Landsat TM & $\begin{array}{l}\text { Corine Land } \\
\text { Cover }\end{array}$ & $\begin{array}{l}\text { Basin Mana- } \\
\text { gement Plan }\end{array}$ & Average & St. Dev. & $\begin{array}{l}\text { St. Dev./ } \\
\text { Average }\end{array}$ \\
\hline Bare soil & 6.43 & 5.94 & 7.45 & 6.61 & 0.77 & 11.66 \\
Grassland & 14.57 & 43.98 & 22.16 & 26.90 & 15.27 & 56.75 \\
Leaf forest & 20.25 & 5.63 & 10.40 & 12.09 & 7.46 & 61.65 \\
Maize & 25.99 & 4.54 & 15.38 & 15.30 & 10.73 & 70.08 \\
Open water & 1.17 & 1.26 & 1.49 & 1.31 & 0.17 & 12.63 \\
Paved areas & 21.00 & 25.84 & 28.10 & 24.98 & 3.63 & 14.52 \\
Pine forest & 10.44 & 12.23 & 14.91 & 12.53 & 2.25 & 17.96 \\
Wetland & 0.14 & 0.57 & 0.11 & 0.27 & 0.26 & 94.16 \\
\hline
\end{tabular}




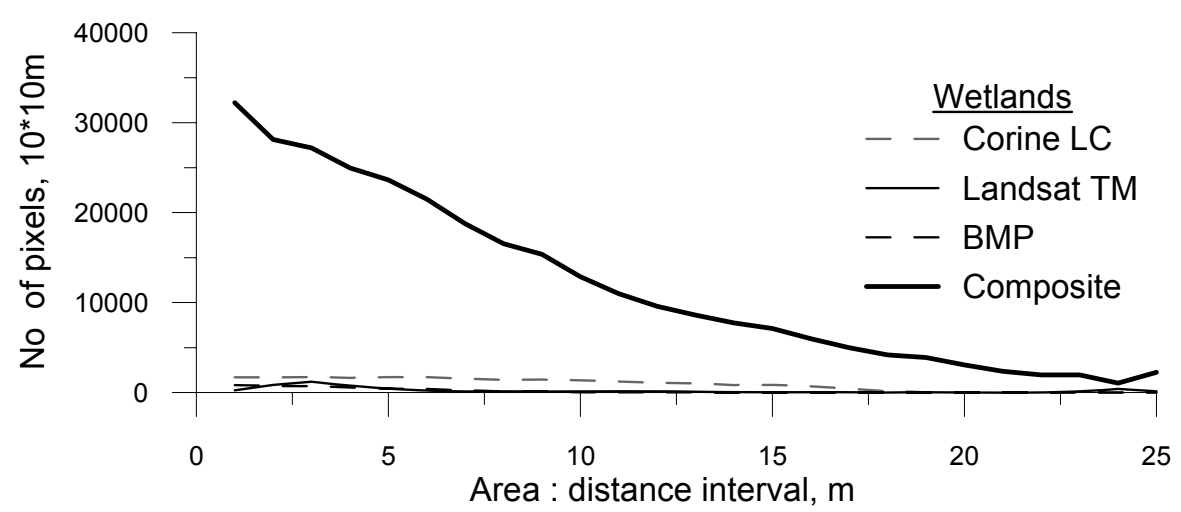

FIGURE 7. Comparison of land use designation in the Corine land cover, Landsat TM, Basin Management Plan (BMP), and composite land use maps for wetlands in function of distance from the streams

complexity and disagreement was observed to be higher in the valleys, which is where smaller parcels and more transitional vegetation patterns occur. This may be the result of the complex land use (vegetation) patterns that occur closer to the valleys which make it more difficult to generate classifications, and the results more easily differ from reality. Transitional and natural vegetation are poorly classified as a result of the need to attribute numerous land use classes to one single land use class per model grid pixel. The level of agreement in land use designation for the different maps varies from 20 to $50 \%$ and rises when moving away from the streams, indicating a more uniform and less complex land use outside the valleys. These trends are even more pronounced when only considering larger streams for the distance functions. The figures are a strong visual example of the challenges and potential ambiguities facing any attempt at classification of land use maps in general, and those of the Grote Nete catchment in our case. This reveals uncertainties as it points out that there are large areas of 'in between' or 'transitional' land use complexes for example, forest and grassland, or open water and forest. But furthermore it complicates the assessment of land-use scenarios.

This study is a good case of an interdisciplinary study involving the disciplines of ecology and engineering, and more so, of how each has complemented the other in seeking a better understanding and solution of land and water resources management challenges. While this research is still ongoing, some benefits that have already become clear as a result of this interdisciplinary approach to the investigation of rewetting include the opportunity for the participating scientists of each discipline to gain an indepth understanding of the perspective from which the other discipline views the challenges to ecosystem management. The scientists have been able to benefit from their combined strengths in addressing different aspects of rewetting. It is believed that the coupling between ecological and hydrological modeling tools will bring the strengths of both disciplines to bear in understanding the 
likely effects of river valley rewetting. In addition, robust statistical techniques were employed for model calibration and validation, which included a multicriteria model development protocol, with the aim of rendering credibility to the ecohydrological model (Rubarenzya et al., 2006b).

An interdisciplinary team was successfully brought together for this study, an ecohydrological model was built and is being used to represent the hydrological characteristics of the Grote Nete catchment, and realistic rewetting scenarios are being developed and tested. These were all objectives of the research and they have been met. Extreme value statistics are being applied to a number of scenarios as they are developed. The discharge of the Grote Nete at Varendonk was determined to follow an exponential distribution (Willems, 2000). The results from the testing of rewetting scenarios are not yet ready for publication. At the end of this research we should be able to tell whether the proposed action of river valley rewetting in the Grote Nete catchment would have the desired effect of rehydrating the land, and/or whether it would simply augment a decline in the ecosystem health.

\section{ACKNOWLEDGMENTS}

This research is funded through a research grant from the Interuniversity Programme in Water Resources Engineering (IUPWARE).

\section{REFERENCES}

BEVEN K.J. 1985: Distributed modelling. In: Hydrological forecasting, M.G.
Anderson, and T.P. Burt, eds., Wiley, Chichester, UK, 405-435.

BEVEN K.J. 2001: How far can we go in distrbuted hydrological modelling? Hydrology and Earth System Sciences, 5(1), 1-12.

BEVEN K.J. 2002: Uncertainty and the detection of structural change in models of environmental systems. In: Environmental Foresight and Models: a Manifesto, M.B. Beck, ed., Elsevier Science, Ltd., Amsterdam, 227-250.

BOND B. 2003: Hydrology and ecology meet - and the meeting is good. Hydrological processes, 17(10), 2087-2089.

BREUER L., ECKHARDT K., FREDE, H.G. 2003: Plant parameter values for models in temperate climates. Ecological Modelling, 169(2-3), 237-293.

BURROUGH P.A. 1998: Principles of geographical information systems., Oxford University Press, Oxford, UK.

ECKHARDT K., ARNOLD J.G. 2001: Automatic calibration of a distributed catchment model. Journal of Hydrology, 251(1-2), 103-109.

GRAHAM D.N., BUTTS M.B. 2005: Flexible integrated watershed modeling with MIKE SHE. In: Watershed Models, V.P. Singh, and D.K. Frevert, eds., Taylor and Francis CRC Press.

GULLENTOPS F., VANDENBERGHE N. 1995: Toelichting bij de geologische kaart van Belgie", Vlaams Gewest, Kaartblad 17, Mol, Schaal 1:50.000. Ministerie van de Vlaamse Gemeenschap Brussels.

HANNAH D.M., WOOD P.J., SADLER J.P. 2004: "Ecohydrology and hydroecology: A 'new paradigm'?". Hydrological processes, 18, 3439-3445.

HAVNO K., MADSEN M.N., DORGE J. 1995: MIKE 11 - A generalised river modelling package. In: Computer models of watershed hydrology, V. P. Singh, ed., Water Resources Publications, Colorado, USA, 809-846.

HUNT R.J., WILCOX D.A. 2003: Ecohydrology - Why Hydrologists Should Care. Ground Water, 41(3), 289. 
JEWITT G. 2002: Can Integrated Water Resources Management sustain the provision of ecosystem goods and services? Physics and Chemistry of the Earth, 27(11-22), 887-895.

KRISTENSEN K.J., JENSEN S.E. 1975: A model for estimating actual evapotranspiration from potential transpiration. Nordic Hydrology, 6, 70-88.

LIU J., GEBREMESKEL G.S., DE SMEDT F., HOFFMANN L., PFISTER L. 2006: Predicting storm runoff from different land-use classes using a geographical information system-based distributed model.

NIEHOFF D., FRITSCH U., BRONSTERT A. 2002: Land-use impacts on stormrunoff generation: scenarios of land-use change and simulation of hydrological response in a meso-scale catchment in SW-Germany. Journal of Hydrology, 267(1-2), 80-93.

PARENT E., BERNIER J. 2003: Encoding prior experts judgments to improve risk analysis of extreme hydrological events via POT modeling. Journal of Hydrology, 283(1-4), 1-18.

REFSGAARD J.C. 1997: Parameterisation, calibration and validation of distributed hydrological models. Journal of Hydrology, 198, 69-97.

REFSGAARD J.C., STORM B. 1995: MIKE SHE. In: Computer models for watershed hydrology, V. P. Singh, ed., Water Resources Publications, Highland Ranch, Colorado, USA, 809-846.

RUBARENZYA M.H., FEYEN J., WILLEMS P., BERLAMONT J. 2006a: Multi-criteria development and testing of a site-specific model for land and water management. Rep. No NHP Report No 49, PrinfoDjurs, Auning, Auning, Denmark.

RUBARENZYA M.H., WILLEMS P., BERLAMONT J., FEYEN J. 2005: Modelling of river valley rewetting and extreme events in the Nete catchment (Belgium). Taylor \& Francis/ A.A.
Balkema Publishers, Leiden, The Netherlands.

RUBARENZYA M.H., WILLEMS P., BERLAMONT J., FEYEN J. 2006b: Application of WETSPRO tool in MIKE SHE model development and testing. The American Society of Civil Engineers, Proceedings of the EWRI World Environmental and Water Resources Congress, Omaha, Nebraska, USA.

SAMANIEGO L., BARDOSSY A. 2006: Simulation of the impacts of land use/ cover and climatic changes on the runoff characteristics at the mesoscale. Ecological Modelling, 196(1-2), 45-61.

SCHILTZ M., VANDENBERGHE N., GULLENTOPS F. 1993: Toelichting bij de Geologische kaart van Belgie", Vlaams Gewest, Kaartblad (16), Lier, Schaal 1:50 000. Belgische Geologische Dienst, Bestuur Natuurlijke Rijkdommen en Energie.

SMITH R.E., GOODRICH D.R., WOOLHISER D.A., SIMANTON J.R. 1994: Comments on "Physically-based hydrological modelling. Is the concept realistic?" by R.B. Grayson, I.D. Moore and T.A. McMahon. Water Resources Research, 30, 851-854.

STAES J., MEIRE P. 2006: A tool for participatory land-use planning and river basin management. International Seminar on Collaborative Planning of Natural Resources Management, Helsinki, Finnish Environment Institute, Finland.

WILLEMS P. 2000: Probablistic immission modelling of receiving surface waters. $\mathrm{PhD}$ Thesis, Faculty of Engineering, Katholieke Universiteit Leuven, Belgium.

ZALEWSKI M. 2000: Ecohydrology - the scientific background to use ecosystem properties as management tools toward sustainability of water resources. Ecological Engineering, 16(1), 1-8.

Streszczenie: Wykorzystanie modelowania wielodyscyplinarnym podejściu do resytytucji ekosystemów. Artykuł przedstawia badania przedsięwzięte 
w celu analizy wpływu zwiększenia wilgotności na potencjalne efekty odtworzenia ekosystemu zlewniowego rzeki Grote Nete. Gromadząc razem w jednym miejscu wiedzę ekspercką oraz doświadczenia twórców i użytkowników, zarówno modeli ekologicznych, jak i hydrologicznych, celem niniejszego artykułu jest ukazanie, iż zintegrowane badania naukowe są niezwykle istotne z punktu widzenia gospodarowania środowiskiem, jak i perspektywy społeczno-politycznej. Taka jak wiele innych europejskich zlewni, rzeka Grote Nete doświadcza w ostatnim okresie wzrastającej liczby ekstremalnych zjawisk hydrologicznych. Dodatkowo, wartość ekologiczna ekosystemu tej zlewni również systematycznie maleje. Jest to przyczyną pojawiania się problemów związanych z narastającym konfliktem interesów pomiędzy potrzebami rolniczo-urbanizacyjnymi a potrzebami ochrony przyrody. Zwiększenie wilgotności rozważane jest jako jedno z możliwych działań, które może przyczynić się do zatrzymania czy wręcz odwrócenia procesu degradacji ekosystemu zlewni. Jednakże pewnym ograniczeniem związanym ze zwiększeniem wilgotności jest to, iż jego konsekwencje hydrologiczne pozostają w dużym stopniu niewiadome. Model numeryczny został opracowany w celu poznania i oceny potencjal- nych efektów procesu zwiększenia wilgotności w zlewni. Stworzony model SPAN, opisujący sposoby użytkowania ziemi na obszarze zlewni, został połączony z modelem fizycznym o parametrach rozłożonych (MIKE SHE) w kompletny model ekohydrologiczny. Niniejszy artykuł prezentuje proces opracowywania tego kompleksowego modelu wraz $\mathrm{z}$ wynikami jego kalibracji i weryfikacji dla zlewni Grote Nete.

\section{MS. received November 2007}
Authors' addresses:
Mark Henry Rubarenzya, Patrick Willems, Jean Berlamont,
Department of Civil Engineering, Katholieke
Universiteit Leuven, Kasteelpark Arenberg 40, B-3001, Heverlee, Belgium.
MarkHenry.Rubarenzya@bwk.kuleuven.be
Patrick.Willems@bwk.kuleuven.be
Jean.Berlamont@bwk.kuleuven.be
Jan Staes, Patrick Meire
Ecosystem Management Research Group,
University of Antwerp, Universiteitsplein 1, Wilrijk 2610, Belgium.
Jan.staes@ua.ac.be
Patrick.Meire@ua.ac.be 